\title{
Quoting to persuade
}

\section{A critical linguistic analysis of quoting in US, UK, and Australian newspaper opinion texts}

\author{
Jen Cope \\ Australian Catholic University
}

This paper examines how quotations are linguistically constructed by expert contributors in US, UK, and Australian opinion texts, vis-à-vis their form, function, and processes. Cope's (2016) study found that authoritative expert contributors integrated a considerable number of quotations on blame and responsibility for the global financial crisis in single-authored US, UK, and Australian opinion texts. By examining the form, function, and processes of quoting in this paper, she found evidence that quoting is an intertextual form of positioning. Empirically grounded linguistic analyses investigate the language of quoting frames - how the quoted source is specified, the quoting verb used, e.g., strong meanings (demanded, thundered, promised) or neutral (said, told) - and evaluate the language of propositional content in quotations. Such analyses reveal authorial positions taken in quoting. A greater number of quotations incorporated by general newspaper opinion authors, than by specialized financial newspaper opinion authors, furthermore implies that quoting increases a writer's authority in non-specialized media sources. The specially created integrated linguistic framework draws on Martin \& White's (2005) Appraisal system from systemic-functional linguistics, White's $(2012,2015)$ attribution and endorsement, and Bazerman's (2004) intertextuality techniques. Contextual factors in language use and quoting are evaluated throughout. This paper thus provides evidence of, and implications for, quoting in cross-cultural opinion texts, and contributes to knowledge on the increasingly mediatized practice of language recycling and to media literacy.

Keywords: quotation, expert contributors, financial crisis, opinion texts, linguistic analyses, communication strategies, evaluative language 


\section{Introduction}

While journalism guidelines tend to state that facts and opinions must be kept separate (Haapanen, 2017, Section 1.2.1), the converse is clearly apparent in opinion pieces which are published in newspapers. The opinion texts are usually located next to the editorial and on the following page or pages. An opinion text is not an objective news story but presents subjective argumentative text that focuses on events and issues in the wider context (Feez, Iedema, \& White, 2008). Since opinion pieces are often written by people with true expertise of a topic who support opinion with factual information (Columbia University, 2010), it is interesting to find that expert contributors of opinion texts published in the US, the UK, and Australia on the topic of the global financial crisis in 2008 introduce a substantial number of external voices or sources into their opinion text by means of quotation. The three countries were selected because the US was at the epicenter of the 2008 crisis, the UK was severely affected by it, and Australia was less affected than the other two countries. Cope (2018) additionally found that whereas left-leaning political experts voiced blame themselves, US and UK conservative political writers quoted other sources to voice blame.

This paper, therefore, tries to answer certain questions related to the form, function, and processes of quotations in newspaper opinion texts written by experts or people of influence in Australia, the UK, and the USA. An overarching question is: How do writers use quotations to discursively position themselves and others in their discussion of blame and responsibility in US, UK, and Australian newspaper opinion texts during the global financial crisis, and what are the implications of these quoting practices in general, and for media literacy? To answer these questions, the paper is structured as follows. Firstly, it outlines the context of the study and its underlying concepts, as well as its methodological considerations. Secondly, the paper focuses on the qualitative findings to compare between specialized financial and general quality newspapers from the US, the UK, and Australia, showing how direct quotations are linguistically constructed in terms of the quoting frame, that is, how a quotation is attributed to a source as well as the content or proposition of the quotation. It illustrates the types of direct quotations used and their function, for example, whether the opinion authors use a quotation to support or refute an opinion, or whether they use it for dramatic effect. Thirdly, the paper discusses the findings and supports the discussion with recent comments from this study's newspaper opinion writers on their quoting practices. Finally, the paper concludes with the contributions this study makes to the body of knowledge on linguistic recycling and its practical contribution to media literacy. 


\section{Context of the study}

This research study focuses on the form, function, and processes of quotation practices in US, UK, and Australian newspaper opinion texts on the global financial crisis. The aspects examined here derive from a larger study which uniquely distinguished between communication strategies of blame and those of responsibility by expert authors of newspaper opinion texts (Cope, 2016, 2018, forthcoming). In relation to blame and responsibility strategies, quoting is found to be used to varying degrees and for differing purposes.

Previous scholars tended to entwine the concepts of blame and responsibility, mostly subsuming responsibility into blame (see, for example, Abell, 2002; Coates \& Wade, 2004; Hart \& Tindall, 2009; Sneijder \& Te Molder, 2005), whereas Cope (2016, forthcoming) demonstrates that blame and responsibility are separate concepts. She explicates that blame is a negative concept, with blame mostly being attributed to someone deemed to be at fault for an action or having caused a bad situation. Blame can be resisted and communicated through various avoidance, minimization, and denial strategies. Responsibility, conversely, is a more positive concept, with responsibility being accepted, or taken, by making suggestions to resolve or limit a crisis effect in an attempt to move beyond the crisis.

\subsection{Characteristics of an opinion text}

An opinion text generally presents subjective argumentative text that focuses on events and issues more broadly than a news story on a specific topic (Feez, Iedema, \& White, 2008). Sometimes, however, news stories also include bias or subjectivity (Bednarek \& Caple, 2012), for example, when intertwining facts and opinions in selecting and rejecting quotation sources and source material (Haapanen, 2019). Opinion piece writers selected for the current study are either specialist writers (Feez et al., 2008) or people with expertise of the topic who generally support opinion with factual information (Columbia University, 2010). Newspaper opinion pieces, op-eds, or commentaries are usually on the pages starting opposite the editorial page. Sometimes opinion pages are guided by the political leanings of the newspaper, but they are also informed by the desire for a 'balanced forum' (Page, 1996; Wahl-Jorgensen, 2004). Opinion texts are influential with decision-makers in government, corporations, and nonprofit institutions, who read them as often as newspaper lead stories (Columbia University, 2010).

An opinion piece generically introduces an issue, provides arguments or explanations to support the viewpoint, and reiterates the viewpoint or position at the end. Since an opinion piece conveys “.... an event or issue ... to position the reader to 
accept a way of thinking or acting" (Feez et al., 2008, p.67) and to provoke debate (Wahl-Jorgensen, 2004), this paper argues that the act of integrating quotations and external voices is to support authorial positions and is necessary to the provision of authoritative commentary and analysis. Thus, the opinion piece genre, through appropriate analysis, can demonstrate how writers use the linguistic feature of quotation to position themselves and their audience in their texts.

\subsection{Quotation practices and intertextual positioning}

This study draws from Bazerman's (2004) discussion of intertextuality, Martin \& White's (2005) Appraisal system and White's (2012, 2015) notion of intertextual positioning to understand quotation practices and functions. Bazerman suggested that texts can contain several intertextual referencing techniques with quotations being the most explicit form. More implicit resources include phrases relating to different times or places. This paper looks at aspects of intertextuality vis-à-vis the quoting frame in terms of how quotations are attributed and sources specified. It borrows White's $(2012,2015)$ attribution value, from the Engagement framework within the Appraisal system (Martin \& White, 2005) derived from Systemic Functional Linguistics (Halliday, 1985), as a way for speakers and writers to incorporate other sources to support their ideas. Attributing an idea or quotation to a source subdivides into how closely or distantly a writer positions themself in relation to an attributed source (Martin \& White, 2005).

The quoting frame, which surrounds some quotations, provides information on the source as well as the reporting verb and other linguistic tokens, all of which can contribute to how an author evaluates the attributed source and quotation. A writer's closeness to the quotation and source can be seen in the use of reporting verbs which 'acknowledge' them, such as, " $X$ said; $X$ believes; according to $X$; in $X$ 's view," or which place higher value on 'endorsing' them using expressions, such as, "X has demonstrated that...; As X has shown..." These latter reporting verbs suggest that the quotation's proposition is valid and positions the writer in alignment with the quotation's attributed source. A writer's distance to the quotation and source, on the other hand, can be seen in the use of reporting verbs, such as, "X claims that, it's rumored that," which tend to position the author as being against or uncertain about the quotation's proposition and quoted source (Martin \& White, 2005, p.98).

The level of authority an author gives to a quotation can be indicated using White's (2015) source specification typology. The typology implies the degree of credibility given to a source, depending on whether a source is named, in a group and/or associated with power. In general, a source is considered more valid and, consequently, provides greater support to a writer's opinion or claim when the 
source is personalized and more narrowly specified (White, 2015). Categories from White's source specification typology which are pertinent to the amount of authority that this study's opinion authors give to quoted sources include:

- personalization - the source is represented as human (personalized) or nonhuman (impersonalized);

- specification - the source is a specific individual or a specific group or a generic class;

- grouping - the source is an individual or a grouping; and

- status - the source's status level in terms of high, low, or unclear according to its authority or power in the community.

Three examples of categorizing sources from my data are:

i. 'Paul Tucker of the Bank of England' (FT2): ${ }^{1}$ human (personalized), specific individual, an individual and high status;

ii. 'economists' (NYT1): human (personalized), generic class, a grouping and status unclear ('unclear' rather than 'high' status, because the frame surrounding the source and quotation indicates that people may not hold them in high regard);

iii. 'the Government ads' (SMH1): non-human (impersonalized), specific group, a grouping and status unclear (the surrounding framing of the source in $\mathrm{SMH}$ - "the ads the Government is spruiking out" - indicates that the writer does not think highly of the advertisements).

The quoting frame can therefore be an important component in interpreting whether an author is favoring or disfavoring a quoted source (White, 2012), and consequently how the author is positioning themself intertextually vis-à-vis the attributed source and quotation.

The current study focuses on the qualitative linguistic construction of direct quotations, sometimes referred to as 'graphologically marked' quotations (Maynard, 1997). Quotation marks generally surround a direct quotation and commonly indicate that a speaker or writer's original words are principally used. As scholars have asserted, however, authors perform a kind of manipulation by selecting a quotation's length and choice of word, i.e., its recontextualization, to support their argument or narrative (Bazerman, 2004; Haapanen, 2017). Quotations found in the opinion texts come from a range of sources, such as, speeches, television advertisements, interviews, written material, and television shows. The variety of source material means, therefore, that its verbatim-ness (in direct quotations) is mostly unsubstantiated. Written interviews with this study's opinion authors tend

1. Please note that details of Data sets follow the list of references at the end of this paper. 
to confirm, however, that the original sources are quoted verbatim or as nearverbatim as is possible. An Australian opinion writer Mark Christensen suggests that while quotations are used "to buttress your own views," he attempts to use a source's exact words and omits but "close-to-never change words" (OA1). Likewise, an American opinion writer Paul Krugman claims to "only use exact words inside quotation marks" (OA2). This paper acknowledges, however, that exactness is relative and questionable in many ways, especially in cases where spoken utterances are transcribed into written form and then quoted (e.g., Haapanen, 2017). Examples for which such exactness of wording is doubted have been omitted from this paper's corpus.

\subsection{Methodological considerations}

This study is located in several research paradigms, with a critical discourse analytic (CDA) perspective underpinning the whole study to highlight issues of power which are linguistically and ideologically embedded within language use (Fairclough \& Wodak, 1997, p.259). As discussed above, the theoretical framework adapts and extends Bazerman's (2004) techniques of intertextuality and Engagement from Appraisal and SFL (Martin \& White, 2005; White, 2012, 2015) to examine the linguistic and rhetorical choices made by writers of the texts in their quoting practices, particularly those which relate to expressions of blame and responsibility. Incorporated quotations indicate authorial positions and, at the same time, they provide contextual insights which are highlighted in the interplay between quotations and the sociopolitical and socioeconomic contexts in which the texts are produced, and connect analyses to the broader issues of power and ideology.

Two types of data are collected for this study: opinion pieces and written interviews with opinion text writers.

A sample of 36 opinion pieces consisting of six pieces from a financial newspaper and six pieces from a general quality newspaper from each of the three countries - the US, the UK and Australia ${ }^{2}$ - was selected according to the following criteria: (i) influential opinion writers, who were mostly external expert contributors, not fully employed by the newspapers; (ii) relevance of the content to the causes and effects of the global financial crisis; and (iii) written within a threemonth timeframe from September 15, 2008, to December 15, 2008. Professional

2. The financial newspapers are The Wall Street Journal (US), Financial Times (UK) and The Australian Financial Review (Australia). The general quality newspapers are The New York Times (US), The Independent (UK) and The Sydney Morning Herald (Australia). 
roles of the writers were usually listed in the text's byline, and form part of the analysis of the relationship between the writer's identity, ideology, and language use.

A small sample of semistructured written interviews was collected from three opinion authors in November 2018. The authors were asked about their quoting practice and process with regard to the opinion piece they wrote in 2008 (included in this study) and how their practice might have changed over time.

\section{Construction, attribution, and function of direct quotations}

This section focuses on how direct quotations are constructed linguistically. It illustrates how quotations are contextualized within the quoting frame: that is, how a quotation is attributed to a source, as well as the quotation's propositional content, and whether the author uses the quotation to support or refute their or another source's opinion, especially in relation to communicating blame or responsibility for the global financial crisis.

Two main types of direct quotation are found, which are broadly categorized as: labeling or short-phrase - consisting of either one-, two- or three-word phrases - and lengthy quotations - consisting of lengthier clauses and sentences, which can include serious 'factual', literary, or anecdotal references. 'Self-quotation' (Maynard, 1996), in which an opinion writer quotes themself, constitutes a further type within lengthy quotations.

The following sub-sections are firstly organized into quotation type; then, within the quotation type, examples are grouped according to financial and general newspapers. This allows insights into contextual factors and their effect on financial and general opinion authors incorporating quotations, i.e., whether the quotation serves to support or distance the quoter from an opinion. Quotation examples are representative of the most typical type and function of quotation.

\subsection{Short-phrase quotations}

In short-phrase quotations, the source is sometimes not identified and, where it is, it tends not to be narrowly specified. Short-phrase quotations are found in all datasets and relate to specialized banking, financial, and economic terminology, banking practices, or to common everyday terms. Labeling is often a function of a short-phrase quotation. 


\subsubsection{Financial newspapers}

The short-phrase quotation is particularly prevalent in the US financial texts, often labeling banking or financial practices and is non-attributed. UK financial datasets contain short-phrase quotations with a mix of identified and unidentified sources. The Australian financial dataset contains a substantial number of shortphrase quotations that relate to banking practices, similar to the US and UK financial texts.

The quoted phrase "irrational exuberance" occurs in two different US financial texts, whose authors are respectively, in Example (1), Gerald O’Driscoll Jr, a senior think tank fellow and a former vice president of the Federal Reserve Bank of Dallas, and in Example (2), Judy Shelton, an economist:

(1) The central bank needed to counter the "irrational exuberance" of the dot-combubble.

(2) ... an elastic currency to soften the blow of economic contractions caused by "irrational exuberance" (and that will never be conquered, so long as humans have aspirations)...

Neither example attributes the phrase to a source, and both seem to label the financial practice and behavior negatively; the effect of these features being to distance the writer from the practice/behavior. According to Alan Greenspan (2007), the US former Federal Reserve Chairman, he first used the phrase "irrational exuberance" in his 1996 speech given during the dot.com bubble of the 1990s, when he warned that asset values might be declining. Example (1) introduces the phrase with the words 'needed to counter'; the writer thereby positions himself as critical of the Federal Reserve's 1990's role in making it too easy to borrow money. In Example (2), the phrase is introduced with the reporting verb 'caused by' and appears in the midst of a relatively long sentence that explains that the Federal Reserve (central bank of USA) was created in 1913 to mediate against the effects of irrational exuberance, but could not successfully control the effects of the crisis.

Two phrases relating to banking practices can be found in the consecutive sentences in Example (3), from a UK text written by Phillip Augar, a former managing director of a British asset management company.

(3) "Originate and distribute" banking was all the rage. The investment bankers claimed to have "transformed risk" through their credit derivatives, off-balance sheet vehicles and securitisations.

The phrases appear as if they represent recommendations from bankers, even though neither phrase was clearly accredited. By framing the first quoted phrase with Augar's comment that it was 'all the rage', makes the quoted banking technique 
seem as though it occurred only because it was fashionable at the time, and was not based on good banking practice nor in the best interests of stakeholders. The use of the reporting verb 'claimed' in the second sentence infers a sense that this was not what actually happened according to Augar, distancing him from the bankers' claim and implies his lack of belief in, and, hence, criticism of the banking practices. The 'investment bankers' as quoted source can be classified as a non-personalized grouping, whose status within the context of the sentence appears to be low.

Examples (4) and (5) are from the Australian financial text of Mark Christensen, an independent economic consultant, who argues how economic uncertainty cannot be bound by government control, i.e., that there will always be a level of uncertainty. John Hewson, an economist and a former Australian conservative political leader, in Example (6) names Australian banking practices (which parallel those in the US) as contributing to the economic downturn:

(4) When Adam Smith alerted us to "the invisible hand", governments began to accept there was no formula for putting our limited resources to best use. (AFR1)

(5) Without a viable alternative, opponents of the market resort to impractical concepts such as "good" regulation...

(6) And, rather than increasing lending, they (Australian banks) are what they call "de-leveraging" and/or "repricing risk"...

Christensen uses the short-phrase quotations in two different ways. Example (4) accredits the quoted phrase to an authoritative named source - Adam Smith, a well-known authoritative 18th century economist and philosopher - and indicates positivity in the reporting verb 'alerted us to'. In Example (5), however, the verb 'resort to' indicates negative evaluation, while Christensen denotes irony in putting quotation marks around the 'impractical' concept of 'regulation' being considered "good," and thus calls "into question the validity of the claim" (OA1). Hewson in Example (6) implies the banking practices are unsuitable, by negatively evaluating the wording that precedes the quoted fragments, with the insertion of the clause beginning 'rather than..., and subsequently continuing with '...what they call'. Hewson thus distances himself from the quoted banking practices either because he believes that the names are inappropriate or, more probably, he disapproves of the practices being carried out by the Australian banks. 


\subsubsection{General newspapers}

Short-phrase quotations in the general newspapers are less about naming banking practices and more about naming ideologies, quoting slogans, or referring to everyday terms, in comparison with the financial newspaper texts.

Barbara Ehrenreich in her US general newspaper text uses a short-phrase quotation to label a practice connected to the topic of positive thinking which she blames in part for the financial crisis, along with greed and speculation.

(7) As promoted by Oprah Winfrey, scores of megachurch pastors and an endless flow of self-help best sellers... "visualizing" something - ardently and with concentration - actually makes it happen.

In Example (7), the notion of "visualizing" is attributed to a range of sources, including the populist television personality Oprah Winfrey. The quantifiers 'scores of' and 'an endless flow of', together with the non-personalized groupings of 'megachurch pastors' and 'self-help best sellers', however, function to distance the opinion author Ehrenreich from the claim that to visualize an outcome 'actually makes it happen.' This example also represents a type of implicit or indirect blame.

Example (8) is from Tim Lott's UK general newspaper text, in which he names a non-financial phenomenon as contributing to the financial crisis.

(8) You could say that everyone who could got involved, so it was only common sense, and we can't blame those sacred collective individuals "The People". (Ind2)

The effect of Example (8), with the people in quotation marks and capital letters, serves to highlight the distinction between those ordinary people and those holding powerful positions as in the City of London who were to blame. Lott seems to overstate that the regular people cannot be blamed for the crisis through his evaluation of them as 'sacred collective individuals'. This labeling of them makes sense when viewed within the overall development of Lott's argument in his text that many people did opportunistically take part in events leading up to the crisis, yet there were others, including Lott himself, who did not. The verb 'blame' in the example illustrates how blaming constitutes a speech act (Wodak, 2007; Cope, 2018).

Gerard Henderson, a think tank institute director, uses short-phrase quotations in his Australian general newspaper text to outline why the Australian Prime Minister, Kevin Rudd, should look for causes of the crisis beyond greed and capitalism. Examples (9) and (10) provide two phenomena in quotation marks, sourced from Rudd, which refer to the ideology of capitalism, and its causation of the global financial crisis: 
(9) However, it is to be hoped the Prime Minister does not really believe the international financial crisis can be totally attributed to what he termed the "extreme capitalism"...

(10) Which suggests that what the Prime Minister terms "extreme free-market ideologues" have not prevailed Down Under.

Henderson constructs Examples (9) and (10) in similar ways. Henderson's prefacing and follow-up comments of the quotations argue against Rudd's perceived belief that Australia was not affected in the same way as the US and therefore does not need to apply similar solutions. The repetitive elements of the quotations from the Australian Labor Prime Minister, Kevin Rudd, both of which include the adjective 'extreme', and the quoting frame inclusion of 'what he termed' and 'what the Prime Minister terms' respectively in Examples (9) and (10), imply that Henderson is positioning himself at the other end of the political spectrum from Rudd. Whereas Henderson displays his conservative and more right-leaning attitudes in discrediting Rudd's ideas, Rudd is intertextually positioned as a quite strident left-leaning Australian political leader. The tentativity seen in the language surrounding the quotations verges on politeness and contrasts quite sharply with the implicit meanings underlying these examples.

\subsection{Lengthy quotations including literary and anecdotal types}

Financial and general newspapers texts usually attribute quotations to clearly specified sources, which are mostly authoritative. This differs somewhat from mostly unattributed short-phrase quotations. Lengthy quotations in the financial newspapers tend to consist of serious 'factual' quotations that relate to banking and finance or that quote political sources. In contrast, lengthy quotations in US and Australian general newspapers tend to relay anecdotes and reference popular culture, whereas literary and anecdotal type quotations are noticeably absent from the UK general newspapers.

\subsubsection{Financial newspapers}

Example (11) from Shelton's US financial opinion text illustrates a slightly longer 'factual' statement type quotation with a specified source, George H.W. Bush, who expresses disappointment in Mr. Greenspan, the former Federal Reserve Chairman who had served under four American presidents:

(11) "I reappointed him [Mr Greenspan]," the elder President Bush said. "And he disappointed me." 
The quoted source, George H.W. Bush, implicitly attributes blame to the actions of Mr. Greenspan in the lead-up to the financial crisis because Bush was disappointed that Greenspan kept interest rates very high. The quoted source, President Bush, thus distances himself from Greenspan's unintended actions and exemplifies blame-shifting, a communication blame strategy (Cope, 2016, forthcoming), as well as secondary-voice dialogistic positioning (White, 2012). The neutral reporting verb 'said' indicates the writer's possible agreement with the quoted source and the propositional content of the quotation.

Example (12) from the UK financial text of Howard Davies, a director of the London School of Economics, provides a lengthier quotation attributed to the Bank of England's Mr. Tucker.

(12) And, third, there is the provision of lender-of-last-resort liquidity support, whereby, as Mr Tucker puts it, "central banks have stood ready to provide unlimited amounts of liquidity against good collateral at a rate above the market rate prevailing during peacetime".

The quotation's proposition appears to be a factual description of central banks' practice, which Tucker, in the quotation, evaluates as a generous act (providing 'unlimited amounts of liquidity'). The quoting frame, in which the quotation is attributed to Mr. Tucker, contains the word 'as' preceding the reporting verb 'puts (it). This construction indicates that the opinion author Davies' favors the attributed source and the propositional content of the quotation (White, 2012). Hence, it shows the author's implicit assertion that the central banks have acted responsibly.

Example (13) from an Australian economist, Barry Hughes, shows how he develops his argument in his Australian financial newspaper text on the business cycle halting by quoting a UK-based veteran economist, George Magnus:

(13) In March last year he (Magnus) concluded bluntly: "We can't tell the time but, as sure as eggs is eggs, we know the clock's ticking."

By quoting from what Magnus had said 18 months previously and drawing a parallel between the ticking clock of a bomb and its allusion to the global financial crisis, Hughes appears to concede the accuracy of Magnus' prediction. Hughes' use of the reporting verb 'concluded' indicates the quoter Magnus' 'justification' stance, according to White's (2012) options for secondary-voice dialogistic positioning. The addition of the adverb 'bluntly' strengthens the quoted source's prediction. 


\subsubsection{General newspapers}

US general newspaper text Example (14) illustrates a literary and anecdotal type quotation. The text's author is Paul Krugman, an economist and Professor of Economics, who begins his text with a seemingly lighthearted reference to a joke he made a few months earlier during a meeting of US economists and policy makers to talk about the financial crisis. His text is on the topic of how and why financial market reform needed to happen urgently.

(14) One senior policy maker asked, "Why didn't we see this coming?"

There was, of course, only one thing to say in reply, so I said it: "What do you mean 'we', white man?'

Krugman firstly quotes a senior policy maker and then quotes his own response. Krugman thereby uses the device of self-quoting, enabling readers to 'listen in' on a private conversation (Maynard, 1996), using humor to promote empathy and alignment with the readers. The policy maker's phrasing in the quoted question is quite self-accusatory, by implying their inability to have predicted the crisis. Krugman's quoted response however appears to attempt to take the focus off addressing the main point of the question by questioning the use of the firstperson pronoun in a somewhat irreverent way. Krugman's response, " 'we', white man?," derives from the punchline of a popular 1960 soke in the USA when the Lone Ranger, a fictional masked ranger fighting injustice and his Native American friend Tonto were under attack from Native Americans: the Lone Ranger said to Tonto, "Looks like we're in trouble, Tonto," which prompted Tonto's response that is quoted by, and on behalf of, Krugman in Example (14). It is quite likely that the meaning of these quotations could only be fully understood by those readers who have a deep familiarity with the American cultural context. The inclusion of 'of course, only one thing to say in reply' indicates Krugman's implicit blaming of the senior policy maker for not having been more astute in predicting the crisis.

Certain texts contain a particularly high number of quotations, particularly when they focus on political topics/arguments. Claire Fox, convener of the Londonbased Battle of Ideas in 2008, focuses her UK general text on how people manipulated Karl Marx's ideas and stances on capitalism in relation to the global financial crisis. In Example (15), Fox quotes lengthily from a British political activist, George Monbiot to illustrate how consumption was blamed for the approaching recession:

(15) A year ago, leading environmentalist George Monbiot wrote, "I hope that the recession now being forecast by some economists materialises", as he railed against teenagers with their "expensive haircuts, fashionable clothes and mobile phones" and "cars, which they drive incessantly". 
Fox appears to evaluate the quoted source, Monbiot, positively in describing him as a 'leading environmentalist', together with the neutral reporting verb 'wrote'. Yet, she negatively evaluates Monbiot's ideas in the second reporting verb by using the strong phrasal verb 'railed against' to continue the quotation. This negativity or disfavoring of the quotation's proposition and quoted source by Fox is reinforced by the listing of the consumer goods in the quotation, which somewhat trivialize the causes of the forthcoming recession. Fox overall thus disfavors the quotation, implicitly disagreeing with those who blame materialistic teenagers and consumption generally for the UK financial crisis' accompanying recession.

Miranda Devine's Australian general newspaper opinion text contains several quotations which reference the contemporary and popular culture medium of television advertisements, rather than literature. A fairly well-known Australian conservative writer, Devine in her text writes about the global economic mess having been caused by debt and overspending and focuses on the Australian Prime Minister Kevin Rudd's policy in 2008 of giving government money to Australians to help stimulate the economy.

Example (16), that contains a quotation from a government advertisement, explains how easy it is for Australians to receive the government money (a strategy for Australians to help boost the economy) - and provides further fuel for Devine's position. Example (17) relates to a speech which Rudd made in October 2008 called 'The children of Gordon Gekko', descendants of the fictional character in the 1987 US movie "Wall Street."

(16) ...there are the ads the Government is pumping out..."You do not need to do anything to receive your lump-sum payment," says a cheery voice.

$(\mathrm{SMH} 1)$

(17) He (Rudd) blamed a Gordon Gekko mentality, "obscenity brought about by greed". In a speech in October (2008) he (Rudd) thundered: "We've seen the triumph of greed over integrity; the triumph of speculation over value creation; the triumph of the short term over long-term, sustainable growth."

$(\mathrm{SMH} 1)$

Example (16) reflects Devine's disdain in the phrasal verb 'pumping out', and the evaluative sarcasm that the quoted source is 'a cheery voice' contrasts markedly with the quotation's propositional content of government benefits being given owing to the severe economic situation, while the not needing "to do" anything highlight Devine's position that the government is being extravagant in distributing pointless money.

Example (17)'s reference to the fictional character of Gordon Gekko further parodies and trivializes Rudd and his financial solutions. Devine achieves this in a number of ways. Firstly, the paragraph containing the first part of the quotation quite irreverently uses the pronoun 'He' instead of Kevin Rudd's name. Secondly, the strong reporting verb 'blamed' and fictional 'mentality' make ambiguous whether the initial quotation comes from a factual or fictional source, and implies 
that what Rudd blamed might not be all that meaningful. Thirdly, placing the reference to Gordon Gekko before quoting Rudd's actual words to describe the cause of the global financial crisis. Additionally, Devine's use of the reporting verb 'thundered' before the next part of the quotation in Example (17), and Devine's deliberate selection of the repetitious words which Rudd used, namely, “...the triumph of...," serve as an almost farcical climax, comparable to that of a traditional British pantomime at Christmastime (the text was published in December 2008). Devine, thus, manages to intertextually position herself and attempt to position the readers in distancing them from the Australian Prime Minister and his decisions.

\section{Discussion of quoting in opinion texts}

The linguistic analyses of direct quotations and source specification reveal links to how authors take positions when quoting external voices, with some instances being more clearly defined than others. From the analyses, the reasons for authors incorporating quotations seem to vary.

Firstly, as my analyses reflect, the function of a quotation that is attributed to an authoritative source increases the writer's authority and is often used to support an author's opinion. This occurs more frequently in general newspaper texts than financial newspaper texts. Gerard Henderson, author of an Australian general text, confirmed that he uses quotations to make his arguments more authoritative $\left(\mathrm{OA}_{3}\right)$. Similarly, Mark Christensen, an Australian financial text author, includes quotations for "authority and to link the reader with well-known figures" (OA1). Paul Krugman, a US general text author, taking a slightly different perspective from Henderson and Christensen, says that he is, however, "more likely to use quotations for a general audience" to break up "the straight delivery of ideas" $(\mathrm{OA} 2)$, rather than using quotations to add authority, implying that he is sufficiently authoritative in his own right.

Secondly, my linguistic analyses demonstrate that certain labeling-type quoted phrases, such as "irrational exuberance" (Examples (1) and (2)), carry strong intertextual references to domestic events or previous actions. To understand these references within the recontextualized media relies on assumed knowledge. This pertains, in particular, to short-phrase quotations, which typically act as a type of shorthand or signifier to index a previous event, action or specialized terminology. While reliance on assumed knowledge can help to reduce the numbers of words in a text, it can also constrain understanding to audience members with culturally or contextually related knowledge of those events. Because they are socially and culturally context-dependent, these types of quotations position the writer (and hence audience) intertextually as an insider. The absence of specified sources in short-phrase quotations adds further to their assumed understanding within 
a certain context. From my study, it seems that for writers, the recontextualization of a phrase can be more important than specifying its source, whereas for readers, an identified source can aid them in understanding a phrase's meaning. My analyses suggest, therefore, that newspaper opinion texts are more orientated toward domestic readerships, rather than to the external world. This orientation is acknowledged by an opinion author who pre-adjusts the quotations he uses depending on whether he is "targeting the US or Australia" (OA1).

Thirdly, my linguistic analyses show that longer quotations tend to contain serious 'factual,' literary, or anecdotal material. In contrast to short-phrase quotations, longer quotations are mostly attributed to sources that are specified to differing degrees and that include a few instances of self-quoting. As previously mentioned, a more narrowly specified source carries greater authority than a source that is briefly or generically specified (some people say that), or pluralized (the investment bankers). My findings show that quotations attributed to the latter types of specified source generally function to refute an argument presented by the author within the opinion text. My analyses also reveal that while longer quotations in the financial texts tend to be more serious and related to banking and financial practices, quotations in general texts tend to linguistically recycle political actions, popular culture, or anecdotes. Krugman reiterates this point by acknowledging that he incorporates quotations for the purpose of entertaining or for "dramatic effect, and...to make it clear that I'm talking about real people" $\left(\mathrm{OA}_{2}\right)$ and not to establish his authority. As my text analyses show and opinion authors have confirmed, it is the authors who manipulate the source material and how it is recontextualized into their texts (similarly, see Bazerman, 2004). For some authors, such as Krugman ( $\left.\mathrm{OA}_{2}\right)$, the length and recontextualization of a quotation depends on how easily the external voice's original words fit into an argument, and/or into the text's requisite number of words.

These next two paragraphs consider the main implications of this paper's study. First of all, the quoting frame seems to be as important as the quoted material in terms of understanding intertextual positioning, with the authors' evaluations seen in the type of reporting or attributing verb used and how the source is specified. Writers distance themselves from a quotation and its source by using quoting verbs and constructions that connote negativity, for example: what they call (Example (6)), what he termed (Example (9)), he railed against (Example (15)), and he thundered (Example (17)). Neutral quoting verbs that appear to connote neither negativity nor positivity include said (Example (11)) or asked (Example (14)). Writers, however, align themselves with quotations and sources in which the quoting verb and construction connote positivity or assertiveness, for example: as $M r$. Tucker puts it (Example (12)), concluded bluntly (Example (13)). In addition to the previous points on source specification, sources can be briefly specified according 
to the context. For example, a surname only can be attributed to a quotation when the human source is well-known to an audience, while a full name is attributed when the person is less well-known (OA1). Krugman's brief specification of a source is, however, usually due to "word limits" ( $\left.\mathrm{OA}_{2}\right)$.

A second major implication of this study is that direct quotations in opinion texts are often used to reinforce a point, and mostly draw on the 'actual' words of authoritative or other sources. While expert authors might introduce quotations and external voices into their opinion texts for diverse reasons, with the quotations varying in their function, propositional content and linguistic construction, most quotations serve to support authorial opinions and attempt to persuade readers to align with authorial viewpoints. An author's perceived level of authority can determine the quantity of quotations in a text, a quotation's function, types of quoting verb, and source specifications used. This is borne out by Christensen who says that, if his quoting practice has changed over time, he uses fewer quotations as a result of "maturity and confidence" as a writer, being aware that writers "don't want to use too many direct quotations or ideas of others. It's about using the material to buttress your own views" (OA1). Krugman, meanwhile, incorporates quotations "to vary the voice, definitely - present it as a kind of argument, rather than a series of flat assertions" (OA2).

\section{Conclusions}

This paper provides evidence that quoting in newspaper opinion texts is an important intertextual feature. US and UK authors are generally positioned as insiders during the global financial crisis, while Australian authors who tend to rely more heavily on external voices are positioned as outsiders. In general newspapers, the greater reliance on quoted sources to convey authority, conversely implies that financial text authors rely more on their own authoritative voice when discussing the financial crisis, notwithstanding some exceptions (e.g., Krugman $\mathrm{OA}_{2}$ ). In addition, specifying sources of quotations is a relatively common practice among opinion writers, and those sources specified as high status contribute to affirming the authoritativeness of the opinion writers.

This study makes theoretical, methodological, and practical contributions to linguistic recycling and media literacy. Theoretically, it contributes to the body of knowledge on linguistic recycling by providing evidence for the 'discursive, translingual and transcontextual process of embedding real or staged-as-real extracts of formerly produced communicational offers' (Haapanen \& Perrin, 2020, this issue) across the cross-cultural domains of financial and general newspaper opinion texts. It demonstrates that the quoting process and practice, whereby 
quotations are instantiated and recontextualized, shape (and are shaped by) linguistic constructions, contextual factors, functions, and meanings. The opinion authors' cognitive processes provide insights into how quoting involves decontextualizing selected words, textualizing them by 'deleting parts and sometimes adding new ones', and en-contextualizing or embedding them into the new discourse (Haapanen \& Perrin, 2020, this issue). This study contributes methodologically in terms of its framework, comparisons made across cultural contexts and two types of newspapers, textual analysis from an etic perspective, and communication with the study's opinion text authors from an emic perspective.

On a practical level, this study demonstrates how, and, to some extent, why, the language users, that is, the opinion writers include other voices in their newspaper texts. It sheds light on the interplay between the writer, the quoted source, the function and propositional content of the quotation and its construction, and how these factors relate to intertextual positioning. Quotations evidently have important functions in the opinion texts, of which this study's opinion writers are conscious and employ in their quoting practice, as they made clear in their comments. Awareness of such aspects is essential to developing media literacy in the broader community, while practitioner reflections on their cognitive processes contribute to scholarly understanding and to the sharing of quoting practices with other media practitioners.

In conclusion, this paper provides evidence of how sociocultural contexts and newspaper subcultures contribute to the language used in quoting practices in newspaper opinion texts, and the important role that quoting plays in opinion texts. Further research in this area can build on this study's findings on quoting to contribute to extending the practices of linguistic recycling in other contexts to benefit academics, practitioners and the broader community.

\section{References}

Abell, J. (2002). Mad cows and British politicians: The role of scientific and national identities in managing blame for the BSE crisis. Text, 22(2), 173-198. https://doi.org/10.1515/text.2002.007

Bazerman, C. (2004). Intertextuality: How texts rely on other texts. In C. Bazerman, \& P. Prior (Eds.), What writing does and how it does it: An introduction to analyzing texts and textual practices (pp. 83-96). Mahwah, NJ: Lawrence Erlbaum Associates.

Bednarek, M., \& Caple, H. (2012). News discourse. London: Continuum.

Coates, L., \& Wade, A. (2004). Telling it like it isn't: Obscuring perpetrator responsibility for violent crime. Discourse \& Society, 15(5), 499-526. https://doi.org/10.1177/0957926504045031

Columbia University. (2010). Writing and submitting an opinion piece: A guide. Retrieved from $<$ www.earth.columbia.edu/sitefiles/file/pressroom/media.../OpEdGuide.doc> 
Cope, J. (2016). Blame, responsibility and positioning in the Global Financial Crisis: A critical analysis of US, UK and Australian newspaper opinion texts (Unpublished doctoral dissertation). The University of Sydney, Australia. <http://hdl.handle.net/2123/15719>

Cope, J. (2018). Expressions of blame for the Global Financial Crisis in US, UK and Australian opinion texts. In M. Patrona (Ed.), Crisis and the media: Narratives of crisis across cultural settings and media genres (Ch. 3, pp. 59-84). Amsterdam: John Benjamins. https://doi.org/10.1075/dapsac.76

Cope, J. (forthcoming). Assigning blame or taking responsibility: Communication strategies to resist and move beyond a crisis. Bristol: Multilingual Matters.

Fairclough, N., \& Wodak, R. (1997). Critical discourse analysis. In T.A. van Dijk (Ed.), Discourse as social interaction (pp. 258-284). London: Sage.

Feez, S., Iedema, R., \& White, P. (2008). Media literacy. Sydney: NSW Adult Migrant Education Service.

Greenspan, A. (2007). The age of turbulence. New York, NY: Penguin.

Haapanen, L. (2017). Quoting practices in written journalism. Article-based doctoral dissertation, University of Helsinki. https://helda.helsinki.fi/handle/10138/174618

Haapanen, L. (2019). Modelling quoting in newswriting: A framework for studies on the production of news, Journalism Practice, 14(3), 374-394. https://doi.org/10.1080/17512786.2019.1618199

Haapanen, L., \& Perrin, D. (2020). Introduction to 'Linguistic recycling: The process of quoting in increasingly mediatized settings', AILA Review, 33. https://doi.org/10.1075/aila.00027.int

Halliday, M.A.K. (1985). An introduction to functional grammar. London: Edward Arnold.

Hart, P., \& Tindall, K. (Eds.) (2009). Framing the global economic downturn: Crisis rhetoric and the politics of recessions. Canberra: ANU E Press.

Martin, J.R., \& White, P.R.R. (2005). The language of evaluation: Appraisal in English. Houndmills: Palgrave Macmillan. https://doi.org/10.1057/9780230511910

Maynard, S.K. (1996). Multivoicedness in speech and thought representation: The case of selfquotation in Japanese. Journal of Pragmatics, 25(2), 207-226. https://doi.org/10.1016/0378-2166(94)00097-2

Maynard, S. K. (1997). Textual ventriloquism: Quotation and the assumed community voice in Japanese newspaper columns. Poetics, 24(6), 379-392.

https://doi.org/10.1016/S0304-422X(96)00016-2

Page, B. I. (1996). Who deliberates? Mass media in modern democracy. Chicago, IL: Chicago University Press.

Sneijder, P., \& Te Molder, H.F.M. (2005). Moral logic and logical morality: Attributions of responsibility and blame in online discourse on veganism. Discourse \& Society, 16(5), 675-696. https://doi.org/10.1177/0957926505054941

Wahl-Jorgensen, K. (2004). Playground of the pundits or voice of the people? Comparing British and Danish opinion pages. Journalism Studies, 5(1), 59-70. https://doi.org/10.1080/1461670032000174747

White, P.R.R. (2012). Exploring the axiological workings of 'reporter voice' news stories Attribution and attitudinal positioning. Discourse, Context \& Media, 1, 57-67. https://doi.org/10.1016/j.dcm.2012.10.004

White, P.R.R. (2015). 4. Intertextual positioning. Retrieved from <http://www.grammatics .com/appraisal/appraisalguide/framed/frame.htm> (13 May, 2020). 
Wodak, R. (2007). Pragmatics and critical discourse analysis. Pragmatics \& Cognition, 15(1), 203-225. https://doi.org/10.1075/pc.15.1.13wod

\section{Data sources}

\section{Sample A. Opinion authors and newspaper references}

\section{US financial texts}

WSJ1 O’Driscoll Jr., G.P. (2008, November 17). To prevent bubbles, restrain the Fed. The Wall Street Journal, p. A19. Retrieved from <http://www.wsj.com/articles

/SB122688652214032407>

WSJ2 Shelton, J. (2008, September 30). Loose money and the roots of the crisis. The Wall Street Journal, p. A19. Retrieved from <http://www.wsj.com/articles

/SB122273029076687929>

\section{US general texts}

NYT1 Ehrenreich, B. (2008, September 23[online], September 24 [print]). The power of negative thinking. The New York Times, p. A27. Retrieved from <http://www.nytimes .com/2008/o9/24/opinion/24ehrenreich.html?_r=o>

NYT2 Krugman, P. (2008, November 27 [online], November 28 [print]). Lest we forget. The New York Times, p. A43. Retrieved from <http://www.nytimes.com/2008/11/28/opinion /28/krugman.html>

\section{UK financial texts}

FT1 Augar, P. (2008, September 28 [online], September 29 [print]). The Big Bang model that blew up in our faces. Financial Times, p. 17. Retrieved from $<$ http://www.ft.com/intl/cms /s/o/247923f8-8d8e-11dd-83d5-0ooo779fd18c.html\#axzz40CSkwc5o>

FT2 Davies, H. (2008, September 30 [online], October 1 [print]). New banking rules: tread carefully. Financial Times, p. 17. Retrieved from <http://www.ft.com/intl/cms/s/o /87edgbda-8foa-11dd-946c-oooo779fd18c.html\#axzz4oCSkwc5o>

\section{UKgeneral texts}

Ind1 Fox, C. (2008, October 27). Not, please, in Marx's name. The Independent, p. 37. Retrieved from Factiva database. Document INDooooo20081027e4arooo1q

Ind2 Lott, T. (2008, October 12). Don't blame this all on the greedy City [print title]. The Independent, p. 40. Retrieved from Factiva database. Document INDOSooo20o81012e4ac 0002l

\section{Australian financial texts}

AFR1 Christensen, M. (2008, November 22). Uncertainty... it's something we should count on. The Australian Financial Review, p. 63. Retrieved from Factiva database. Document AFNRoooo20111231e4bmooqoh

AFR2 Hewson, J. (2008, November 21). Make our banks play fair. The Australian Financial Review, p. 74. Retrieved from Factiva database. Document AFNRoooo20111231e4blooq2s 
$\mathrm{AFR}_{3}$ Hughes, B. (2008, September 22). Business cycles shudder to a halt. The Australian Financial Review, p. 71. Retrieved from Factiva database. Document AFNRoooo20111231e49moouo1

\section{Australian general texts}

SMH1 Devine, M. (2008). Cash-machine Kev to the rescue. The Sydney Morning Herald, p. 17. Retrieved from http://www.smh.com.au/news/opinion/cashmachine-kev-to-the-rescue /2008/12/10/1228584922978.html

SMH2 Henderson, G. (2008). Do-gooders helped make the mess. The Sydney Morning Herald, p. 13. Retrieved from <http://www.smh.com.au/news/opinion/gerard-henderson /gerard-henderson/2008/10/o6/1223145255826.html?page=2 >

Sample B. Written interview responses

OA1 Mark Christensen (November 7, 2018)

$\mathrm{OA}_{2}$ Paul Krugman (November 15, 2018)

$\mathrm{OA}_{3}$ Gerard Henderson (October 31, 2018)

\section{Address for correspondence}

\section{Jen Cope}

Institute for Learning Sciences \& Teacher Education (ILSTE)

Australian Catholic University

North Sydney Campus, 540.2.08

NSW 2060

Australia

jen.cope@acu.edu.au

jencopeo5@gmail.com 